\title{
PROVOCAÇÕES COMPARTILHADAS EM VERSOS E FOTOGRAFIAS: ÁLBUM, DE RUI PIRES CABRAL
}

\author{
Tamy de Macedo Pimenta \\ (Universidade Federal Fluminense)
}

\begin{abstract}
Álbum, de Rui Pires Cabral, ${ }^{1}$ é uma edição artesanal de apenas cinquenta e dois exemplares publicada pela Nenhures em outubro de 2013. Assemelha-se à primeira vista muito mais ao que seu título evoca - um álbum de fotografias - do que a um livro de poesia, já que ao folhear o pequeno livro deparamo-nos com fotos em preto-e-branco dispostas em páginas negras, protegidas por duas folhas de papel manteiga, uma ao início e outra ao final. Embora num primeiro momento pareçam ter somente a função de proteger as fotos,

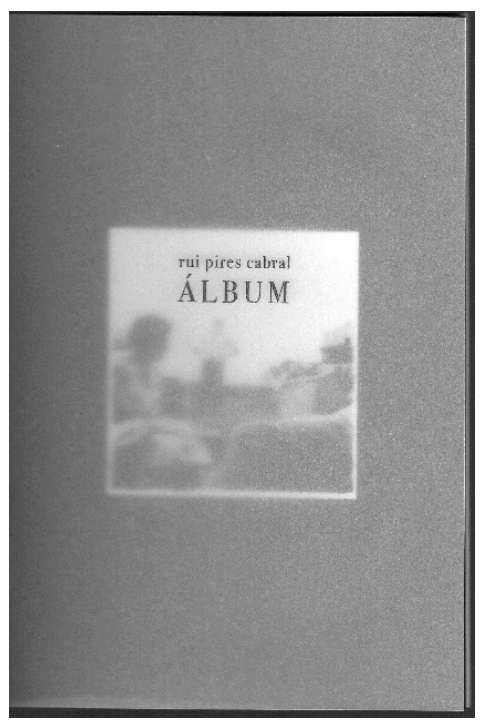
encontramos nessas mesmas páginas a inscrição do título do livro e informações sobre a edição, além da assinatura do autor e a numeração do exemplar feita pelo mesmo, o que - juntamente com a presença de palavras e frases coladas sobre as fotos - permite-nos identificar um livro.
\end{abstract}

A poesia nele apresentada, porém, é diferenciada do que normalmente se poderia achar em obras poéticas, na medida em que os versos são compostos por recortes de palavras ou frases que, por sua vez, são afixados sobre velhas fotografias. Imagem e palavra, fotografia e poesia, estão, portanto, associados intrinsecamente: é o que o próprio poeta nomeia "poemas-colagens". 
O diálogo com a fotografia já fora feito por Rui Pires Cabral quando este organizou em 2012, juntamente com a ilustradora Daniela Gomes, o livro Nós, os desconhecidos, formado por vinte e seis poemas de autores diversos escritos a partir de fotografias antigas de anônimos, dispostas ao lado dos poemas. No mesmo ano, o autor publicou Biblioteca dos Rapazes, inaugurando seu trabalho com a poesia-colagem que continuaria em Broken (2013b), Stardust (2013c) e OH! LUSITÂNIA (2014). Entretanto, se nestes as imagens e fotos são recortadas e expostas em fragmentos, em Álbum as fotografias são mantidas inteiras, somente alteradas pela inserção de palavras e frases de fontes desconhecidas sobre suas superfícies.

Nessas imagens são encontrados lugares comuns que podem ser reconhecidos em diferentes contextos, como rios, montanhas, prédios, praças, ruas e casas; e, quando há pessoas, elas estão ao longe, como sombras, ou com os rostos desfocados, sem singularidade perceptível. Essas figuras são como as personagens retratadas pelo pintor alemão Caspar David Friedrich, que perdem sua personalidade já que "permanecem, geralmente, como silhuetas [...] desprovidas de rosto e de individualidade." (COLLOT, 2013, p. 96) Assim, os lugares e pessoas presentes nas fotos podem dialogar com o leitor, na medida em que este preenche o que não pode ver com sua imaginação. Ocorre então "um diálogo em que o leitor coloca no que lhe é contado o que ele tem de experiência existencial." (MAGALHÃES, 1999, p. 274): ao olhar as fotografias, o leitor olha também a si mesmo naquelas imagens.

\section{Quadro Nascer da lua sobre o mar}

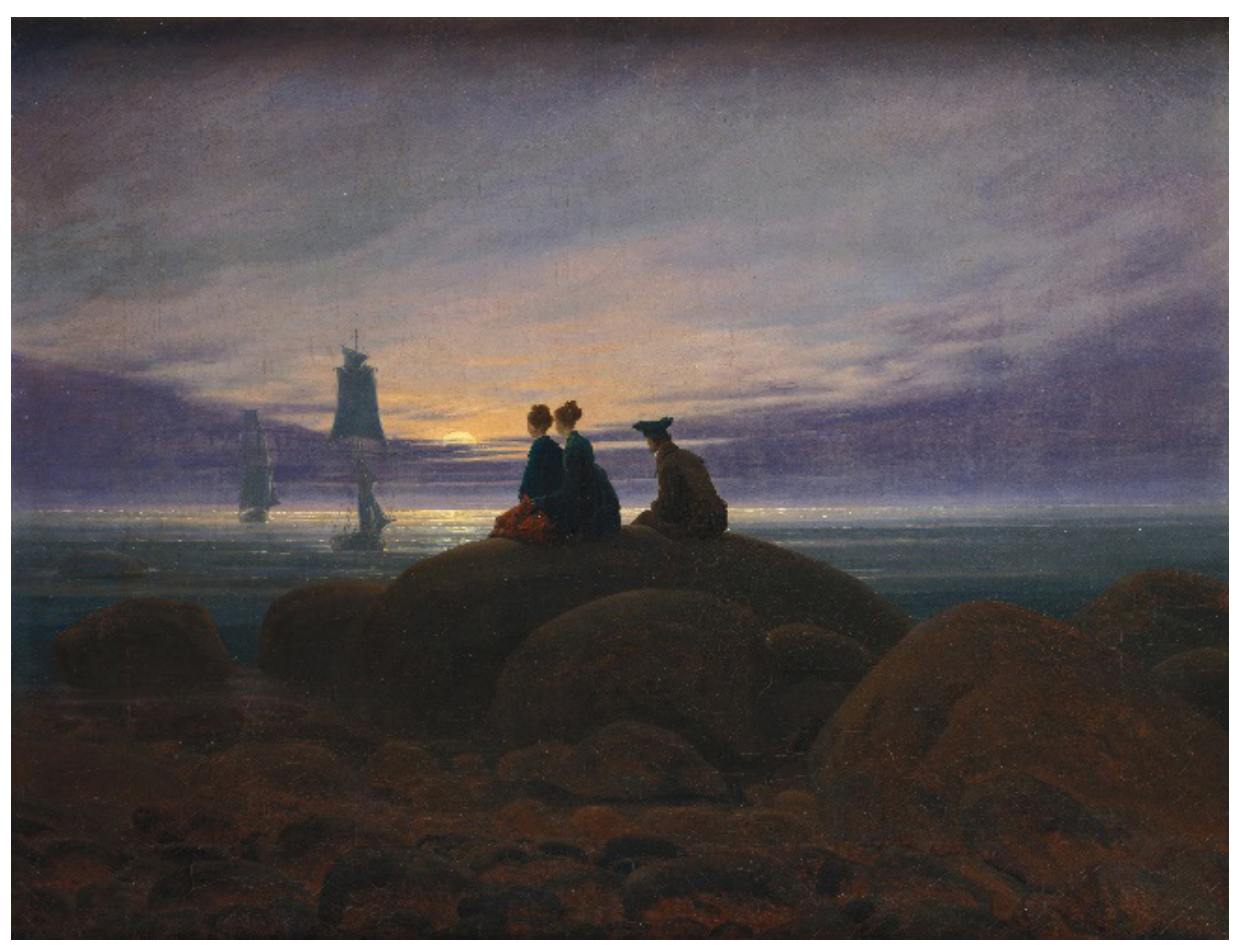

Friedrich, 1822, óleo sobre tela 55 x $71 \mathrm{~cm}$

Berlim, Nationalgalerie 


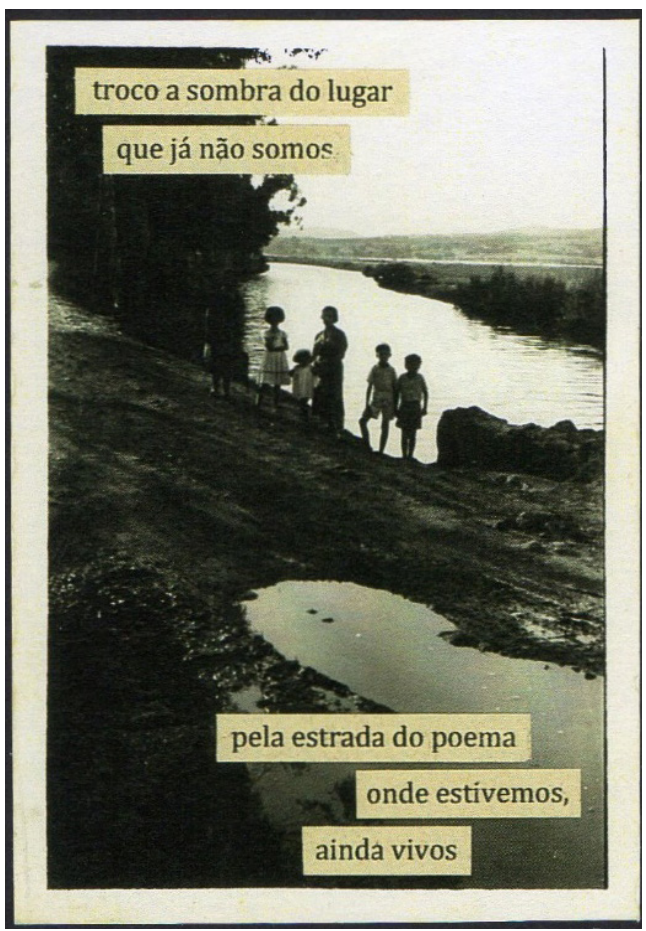

(CABRAL, 2013a, s/p)

Essa partilha com o leitor também é observada no conteúdo dos versos de Álbum, que funcionam como provocações mobilizadoras de reflexões acerca de nossa contemporaneidade arruinada. Os dez poemas-colagens que compõem o livro dialogam entre si constituindo um todo de sentido, permitindo que esta nova obra de Cabral seja lida como um livro-poema de experiências e reflexões compartilhadas com o leitor. Desde sua confecção, Álbum parece endereçado a seus receptores/leitores: o frágil livro vem dentro de um envelope azul-escuro - quase como uma carta - e, ao abri-lo, os leitores deparam-se com um exemplar único, numerado e autografado pelo poeta, que ainda fixou cada poema-colagem em sua respectiva página negra. Estratégia similar já havia sido adotada em Stardust, composto por um poema, que é o mesmo em todos os exemplares, e uma colagem única e original, feita manualmente por Rui Pires Cabral em cada livro, na página seguinte. Enquanto neste cada leitor recebeu uma colagem para si, em Álbum a interlocução autor-leitor ocorre de maneira distinta, de forma a realçar a comunicação entre os dois por meio do uso constante de interrogações/interpelações ("em que tempo/ e lugar// chegou a ser/ belo// o vosso futuro?") e imperativos/conselhos ("Não tenhas medo.// Isto passa num instante"). Além disso, o emprego da segunda pessoa do plural e da palavra "Juntos" reforça a aproximação entre o Eu dos versos e o eu que os lê. Cria-se, então, simultaneamente, por um lado, um diálogo entre autor e leitor, que se transformam, respectivamente, em emissor e receptor; por outro, uma identificação por parte do leitor com o eu lírico através da partilha de emoções e pensamentos comuns aos sujeitos sobre a condição humana no contemporâneo, em que a distopia, o vazio e a fugacidade são elementos constantes. 
Dentro desse contexto de tempo e espaço arruinados, onde só há "vestígios de lume/ e matéria/ às escuras" (CABRAL, 2013a, s/p), o que resta é fugir e tentar fazer cessar o vazio que se sente trocando "a sombra do lugar/ que já não somos// pela estrada do poema/ onde estivemos,/ ainda vivos". A poesia é, então, o lugar onde ainda se pode viver, em comunhão:

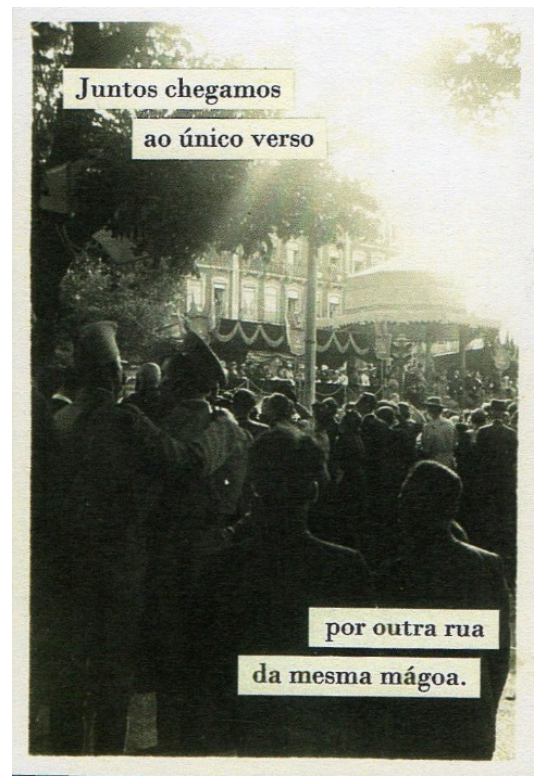

(CABRAL, 2013, s/p)

Longe de remediar os males do mundo, a poesia - assim como o livro em questão - é somente uma frágil forma de escape. Ainda que imerso no corpo do poema, o sujeito reflete sobre sua corporeidade física refém da opacidade e escuridão dos tempos:

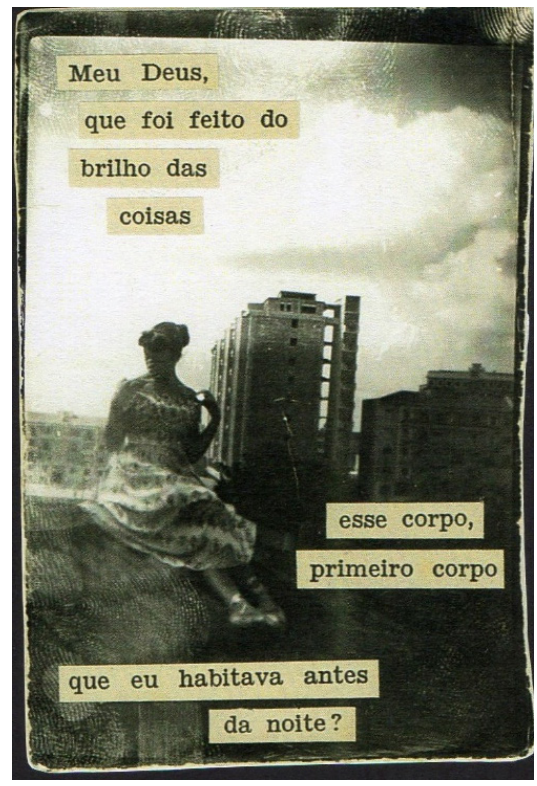

(CABRAL, 2013a, s/p) 
Nesse sentido, o trânsito entre mundo real e ficcional, corpo físico e poemático, deve ser constante, constituindo-se em um movimento insistente do qual o leitor também participa, na medida em que é convocado e provocado pelos versos de um livro que, propositalmente sem ponto final, indica a perpétua continuidade de sua inquietação:

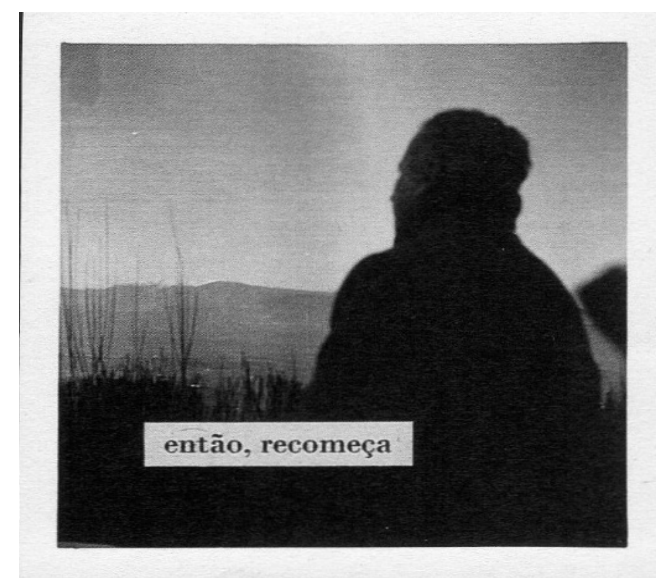

(CABRAL, 2013a, s/p)

\section{REFERÊNCIAS BIBLIOGRÁFICAS}

CABRAL, Rui Pires; GOMES, Daniela (Orgs.). Nós, os desconhecidos. Lisboa: Averno, 2012a.

CABRAL, Rui Pires. Biblioteca dos Rapazes. Lisboa: Pianola, 2012b. . Álbum. Lisboa: Nenhures, 2013a. . Broken. Lisboa: Paralelo W, 2013b. . Stardust. Lisboa: Nenhures, 2013c. . OH! LUSITÂNIA. Lisboa: Paralelo W, 2014.

COLLOT, Michel. Poética e Filosofia da Paisagem. Rio de Janeiro: Oficina Raquel, 2013.

MAGALHÃES, Joaquim Manuel. Rui Pires Cabral. In: Rima pobre. Lisboa: Presença, 1999.

Recebido para publicação em 27/11/14 Aprovado em 18/01/15

\section{NOTAS}

1 Poeta e tradutor formado em História pela Universidade do Porto, nascido em Macedo de Cavaleiros, Portugal, no ano de 1967. Seu primeiro livro, Qualquer Coisa Estranha, de contos, foi publicado em 1985 e a ele se seguiram mais quatorze, de poesia: Pensão Bellinzona e Outros Poemas (1994) Geografia das estações (1994), A super-realidade (1995), 
Música antológica \& onze cidades (1997), Praças e quintais (2003), Longe da aldeia (2005), Capitais da solidão (2006), Oráculos de cabeceira (2009), A Pocket Guide to Birds (2009), Biblioteca dos Rapazes (2012), Broken (2013), Stardust (2013), Álbum (2013) e OH! LUSITÂNIA (2014). Seus poemas estão presentes em antologias, cujas principais são Anos 90 e agora: uma antologia da nova poesia portuguesa (2001), Poetas sem qualidades (2002), 9 poetas para o século XXI (2003) e o segundo volume de Portugal, 0 (2007). Como tradutor de língua inglesa, destacam-se os trabalhos com os livros Uma Casa no Fim do Mundo, Sangue do Meu Sangue e Dias Exemplares de Michael Cunningham. 